\title{
RADIOIMMUNOASSAY OF THYROTROPIN-RELEASING HORMONE (TRH) IN RAT, DOG, AND HUMAN BLOOD
}

\author{
SHIGEHARU YOKOHAMA, KENJI YAMASHITA, HAJIME TOGUCHI AND NOBUYUKI KITAMORI \\ Central Research Division, Takeda Chemical Industries, Ltd., Juso-honmachi, Yodogawa-ku, Osaka, \\ 532, Japan
}

(Received March 10, 1983)

\begin{abstract}
A radioimmunoassay was developed for the measurement of exogenous thyrotropin-releasing hormone (TRH) in the whole blood of rats, beagle-dogs and humans. Even at low temperature, TRH is degraded so quickly in the whole blood that stabilization of TRH in the blood is necessary. For this purpose, the direct extraction with methanol and concentration before the radioimmunoassay was satisfactorily performed. The method is highly sensitive so that a lower quantifiable concentration of $20 \mathrm{pg} / \mathrm{ml} \mathrm{was}$ detectable, and good reproducibility and standard errors of less than $10 \%$ from triplicate standard curves were obtained. At low concentration of TRH, the effect of food ingestion and volume of whole blood on the sensitivity of the radioimmunoassay was observed and thin layer chromatographic treatment improved it.

Keywords - thyrotropin-releasing hormone; thyrotropin-releasing hormone tartrate monohydrate; radioimmunoassay; rat whole blood; beagle-dog whole blood; human whole blood
\end{abstract}

Many studies on the biosynthesis, the secretory systems, physiological action, and metabolism of thyrotropin-releasing hormone (TRH; Lpyroglutamyl-L-histidyl-L-prolinamide) have been reproted ${ }^{1-6)}$ since Schally ${ }^{7)}$ and Guillemin ${ }^{8)}$ described its presence in the hypothalamus of sheep, determined its structure, and showed that it stimulated thyroid stimulating hormone release. Furthermore, TRH has been shown to be present outside the hypothalamus in rats and many data have been reported concerning the efficiency of the hormone in clinical studies on antidepressant activity. ${ }^{9-11)}$

In most cases the drug was administered intravenously because it is easy to administer the known dose and the assay was not sensitive enough to detect TRH in blood after oral administration, and also its good stability, high solubility in water and its amorphous and hygroscopic properties. Hatanaka et al. successfully synthesized crystalline thyrotropin-releasing hormone tartrate monohydrate (TRH-T; L-pyroglutamyl-L-histidyl-L-prolinamide-L-tartrate monohydrate), ${ }^{12-13)}$ which has no-hygroscopicity and is convenient to formulate solid dosage forms. The development of a specific radioimmunoassay for the measurement of $\mathrm{TRH}^{3}$ ) enabled us to evaluate pharmacological evidence in the biofluid. However, the elimination rate of TRH in blood is so fast and the absorption from gastrointestine would be slow compared with intravenous injection. Therefore,the blood levels of TRH after oral administration would be rather lower than that of intravenous injection. Moreover, TRH is degraded so quickly in blood $^{14)}$ that some degrading enzyme inhibitors are needed to obtain accurate and reproducible data and to calculate absolute bioavailability. This requirement was one of the reasons why TRH measurement in the serum by radioimmunoassay was difficult and why reproducible data were not obtainable. Some serum TRH degrading enzyme inhibitors have been proposed, i.e., 2,3-dimercapto-1-propanol (BAL); a mixture of EDTA, 8-hydroxyquinoline sulfate, and BAL; and a mixture of 8 -hydroxyquinoline and 
Tween 80.1,6,15,16,24) These inhibitors, however, generally decreased the sensitivity of the radioimmunoassay.

The present paper describes a method for measurement of TRH in the whole blood of rats, beagle-dogs, and humans. The evaluation of the bioavailability of TRH-T and the investigation of its absorption mechanism from gastrointestine would be able to be carried out by this method.

\section{EXPERIMENT}

Animals - Experimental animals used in this study were male Sprague-Dawley (JCL: SD, SPF) rats weighing $240-260 \mathrm{~g}$, and male beagledogs weighing $9.5-10 \mathrm{~kg}$. The volunteer who supplied the human blood was a 37-year old male.

Materials - TRH-T (L-pyroglutamylL-histidyl-L-prolinamide-L-tartrate monohydrate) used was manufactured by Takeda Chemical Industries. The commercial 2,3dimercapto-1-propanol (BAL, Wako Pure Chem.); goat anti-rabbit $\gamma$-globulin serum and normal rabbit serum (DAIICHI Radioisotope Lab.) were used. Anti-TRH serum, ${ }^{25)}$ kindly supplied by Dr. M.Utsumi (was in University of Kobe), was prepared by the procedure described by Bassiri. ${ }^{17)}$ As TRH analogs (to check the cross-reactivity of anti-TRH serum), Lpyroglutamyl-L-histidyl-L-proline (TRH-OH), L-glutamyl-L-histidyl-L-prolinamide (gluhis-proNH ${ }_{2}$ ), L-glutamyl-L-histidyl-L-proline (glu-his-pro), L-glutamyl-L-histidine (glu-his), L-histidyl-L-proline (his-pro) which were synthesized in Takeda, and the commercial Lglycyl-L-glycyl-L-glycine (gly-gly-gly), Lglycyl-L-glycine (gly-gly), L-glycine (gly), Lglycyl-L-proline (gly-pro), and L- $\beta$-alanylL-histidine ( $\beta$-ala-his) (Toyo Kagaku Ltd.) were used. All other materials and solvents were of analytical reagent grade and used without further purification.

Thin Layer Chromatography of TRH - In order to check the accuracy of direct measurements of the radioimmunoassay of $\mathrm{TRH}$, methanol $(\mathrm{MeOH})$ extraction from TRH-T spiked whole blood was developed on a thin layer chromatography (TLC). A stepwise procedure for detection was as follows.

1. $\mathrm{MeOH}(7 \mathrm{ml})$ extraction from TRH-T spiked whole blood ( $1 \mathrm{ml}$, equivalent TRH $1-10$ ng) was spotted on a Merck Silicagel 60 TLC plate after concentration (if necessary).

2. TLC was developed by the method as described by Nakajima et al. ${ }^{18)}$ (solvent; $\mathrm{CHCl}_{3}$ : $\mathrm{MeOH}: \mathrm{NH}_{4} \mathrm{OH}=6: 4: 1$ ).

3. The silicagel layer between $R f 0.45$ and 0.55 was scraped, and extracted with $\mathrm{MeOH}(2$ $\mathrm{ml} \times$ three times).

4. The solvent was evaporated and the residue was dissolved with $1 \mathrm{ml}$ of distilled water; radioimmunoassay of $\mathrm{TRH}$ was then performed.

TLC recovery was determined from the ratio of the direct radioimmunoassay of TRH (TRH spiked in buffer) and of the assay of TLC treated sample of TRH. If the recovery is not sufficient, the ratio would be much smaller than unit. The ability of an additive for a TRH degrading enzyme inhibitor was determined from the ratio of the assay of the TLC treated sample of TRH and of the TLC treated sample of TRH (extracted from whole blood with the inhibitor). If the inhibitor can not inhibit TRH degrading in the blood sufficiently, TRH is degraded and the ratio would be much smaller than unit.

Preparation of ${ }^{275}$ I-Labeled TracerTRH-T was labeled with ${ }^{125}$ I (New England Nuclear. Corp., USA) by the method of Greenwood using chroramine T. ${ }^{19)}$ Twenty microliters of $\mathrm{Na}^{125}$ I $(500 \mu \mathrm{Ci}$; $\mathrm{pH} 7.5,0.3 \mathrm{M}$ phosphate buffer), $10 \mu$ l of chroramine $\mathrm{T}(2 \mu \mathrm{g}, \mathrm{pH}$ 7.5, $0.06 \mathrm{M}$ phosphate buffer) and $10 \mu \mathrm{l}$ of TRH-T (e.q. TRH $2 \mu \mathrm{g}, \mathrm{pH} 7.5,0.06 \mathrm{M}$ phosphate buffer) were mixed in a disposable test tube and the mixture was stirred for $2 \mathrm{~min}$. The reaction was terminated by the addition of 100 $\mu \mathrm{l}$ of sodium metabisulphite $(0.12 \mathrm{mg}, 0.06 \mathrm{M}$ phosphate buffer). One hundred micro-liters of $\mathrm{NaI}(0.2 \mathrm{mg}, 0.06 \mathrm{M}$ phosphate buffer) was added and ${ }^{125}$ I-TRH was separated on a $1 \times 12$ cm column of Sephadex G-10 (Pharmacia Fine 
Chemicals, Sweden). The column was prepared and eluted using $0.06 \mathrm{M}$ phosphate buffer with $0.15 \mathrm{M} \mathrm{NaCl}$ of $\mathrm{pH} 7.5$ according to the method of Bassiri and Utiger, ${ }^{17)}$ and $0.5 \mathrm{ml}$ fractions were collected (Specific activity of ${ }^{125}$ I-TRH was $150 \mu \mathrm{Ci} / \mu \mathrm{g})$.

Radioimmunoassay of TRH - The radioimmunoassay of TRH was performed by the procedure of Bassiri ${ }^{3)}$ with some modification. All reagents were dissolved in an assay buffer, $0.01 \mathrm{M}$ phosphate buffer of $\mathrm{pH} 7.5$ with $0.1 \%$ gelatin, $0.02 \mathrm{M}$ ethylenediaminetetra acetic acid (EDTA-2Na), $0.15 \mathrm{M} \mathrm{NaCl}$, and $0.1 \% \mathrm{NaN}_{3}$. An aliquot of a fraction corresponding to ${ }^{125} \mathrm{I}-\mathrm{TRH}$ was diluted to contain $8000-10000$ $\mathrm{cpm} / 100 \mu \mathrm{l}$ with the assay buffer. TRH radioimmunoassay was as follows. One hundred microliters of diluted antiserum (1:10000) and $500 \mu \mathrm{l}$ of the buffer were added to assay tubes which contained $100 \mu \mathrm{l}$ of diluted TRH-T standard solution or unknown samples with $100 \mu \mathrm{l}$ of ${ }^{125} \mathrm{I}$-TRH. After incubation at $4^{\circ} \mathrm{C}$ or $25^{\circ} \mathrm{C}$ for a few days, $100 \mu$ l of goat anti-rabbit serum $\gamma$ globulin (freeze dried $1.1 \mathrm{ml}$ serum, diluted with $6 \mathrm{ml}$ buffer of the radioimmunoassay) and 100 $\mu l$ of normal rabbit serum (freeze dried $0.22 \mathrm{ml}$ serum, diluted with $6 \mathrm{ml}$ buffer of the radioimmunoassay) were added and additional incubation was carried out at $4^{\circ} \mathrm{C}$ or $25^{\circ} \mathrm{C}$ for a few hours or over-night. After the radioactivities of the samples $\left(T_{\mathrm{c}}\right)$ were counted by an Aloka Autowell $\gamma$-system JCD-752 and centrifuged at $4^{\circ} \mathrm{C}, 3000 \mathrm{rpm}$ for $20 \mathrm{~min}$, the radioactivities of the precipitates were counted $\left(B_{\mathrm{c}}\right)$. A calibra- tion curve was obtained using the mean ratios of $B_{\mathrm{c}} / T_{\mathrm{c}}$ versus the logarithms of TRH-T concentrations $(\log c)$, and also using the $\log i t B / B_{\text {o }}$ $\left(\log \left(B / B_{\mathrm{o}} /\left(1-B / B_{\mathrm{o}}\right)\right)\right.$, where $B=B_{\mathrm{c}} / T_{\mathrm{c}}$ of the sample and $B_{\mathrm{o}}=B_{\mathrm{c}} / T_{\mathrm{c}}$ in the TRH free buffer) versus the $\log c$ in the buffer.

Specificity of the Radioimmunoassay of TRH - The cross reactivity of the antiserum to TRH analog compounds was studied. The cross reactivity was determined by the ability of the compounds to inhibit ${ }^{125}$ I-TRH binding to the antibody in the buffer solution. The radioimmunoassay was performed with $100 \mu \mathrm{l}$ of diluted antiserum, $500 \mu \mathrm{l}$ of the buffer, $100 \mu \mathrm{l}$ of diluted ${ }^{125} \mathrm{I}-\mathrm{TRH}$, and $1 \mathrm{ng}$ or $10 \mathrm{ng}$ of the TRH analog compounds. The cross reactivity of the analogue was defined as the ratio of the concentration of TRH and of analogue yielding identical displacements of ${ }^{125}$ I-TRH from the antibody.

Whole Blood Assays - TRH assays on the samples (TRH-T was spiked in the whole blood) were performed as follows. One hundred microliters of TRH-T solution (e.q. 1-10 ng of TRH), and $5 \mathrm{ml}$ of an organic solvent (or $100 \mu \mathrm{l}$ of a TRH degrading enzyme inhibitor, BAL) was added to $0.1-1.0 \mathrm{ml}$ of rat, beagle-dog or human TRH free whole blood. The TRH free whole blood was obtained by incubating fresh whole blood for more than one $h$ at $25^{\circ} \mathrm{C}$. After extracting TRH in the sample with an organic solvent and the extract evaporated in a stream of dried $\mathrm{N}_{2}$ gas at $40-50^{\circ} \mathrm{C}$, the residue was dissolved in $1 \mathrm{ml}$ of distilled water and subjected to

TABLE I. The Effect of Incubation Periods on the Standard Deviation of TRH Radioimmunoassay in the Buffer Solution

\begin{tabular}{|c|c|c|c|c|c|c|}
\hline \multicolumn{7}{|c|}{ Incubation Periods } \\
\hline \multirow{2}{*}{$\begin{array}{l}\text { Spiked TRH-T } \\
\text { (pg as TRH) }\end{array}$} & \multicolumn{2}{|c|}{$\begin{array}{l}\text { First inc. } 25^{\circ} \mathrm{C} 24 \mathrm{~h} \\
\text { Second inc. } 25^{\circ} \mathrm{C} 6 \mathrm{~h}\end{array}$} & \multicolumn{2}{|c|}{$\begin{array}{l}\text { First inc. } 25^{\circ} \mathrm{C} 24 \mathrm{~h} \\
\text { Second inc. } 4^{\circ} \mathrm{C} 24 \mathrm{~h}\end{array}$} & \multicolumn{2}{|c|}{$\begin{array}{l}\text { First inc. } 4^{\circ} \mathrm{C} 5 \mathrm{~d} \\
\text { Second inc. } 4^{\circ} \mathrm{C} 24 \mathrm{~h}\end{array}$} \\
\hline & $\overline{\mathrm{X}}$ & $\sigma_{n-1}$ & $\overline{\mathrm{X}}$ & $\sigma_{n-1}$ & $\frac{\operatorname{second}}{\bar{X}}$ & $n-4<24 n$ \\
\hline 160 & $36.7 \%$ & $0.9 \%$ & $44.9 \%$ & $0.6 \%$ & $42.2 \%$ & $0.1 \%$ \\
\hline 1280 & $22.4 \%$ & $1.2 \%$ & $25.3 \%$ & $0.3 \%$ & $25.1 \%$ & $0.2 \%$ \\
\hline
\end{tabular}


the radioimmunoassay.

\section{RESULT AND DISCUSSION}

Condition of Radioimmunoassay

Six replicate assays were carried out to study

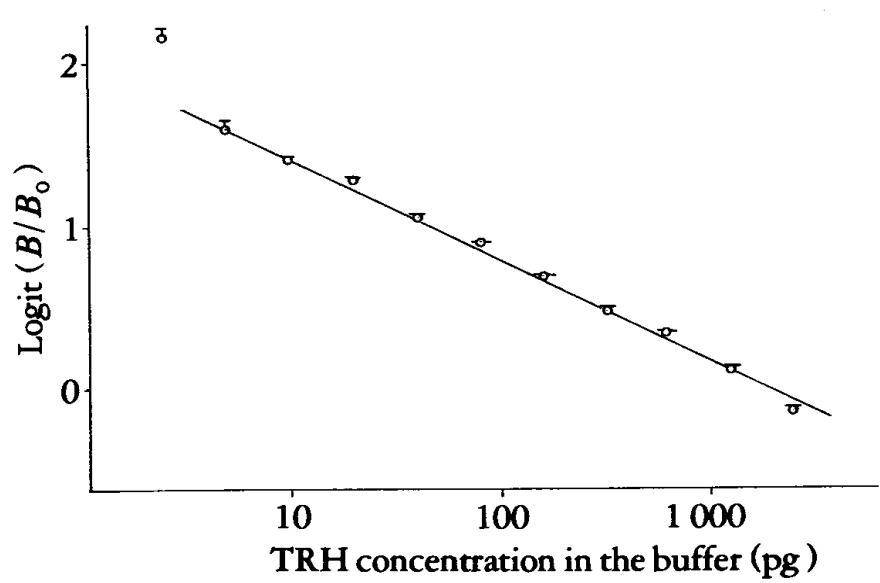

FIG. 1. Standard Curve of TRH in the Radioimmunoassay Data are represented as means $\pm S . E$. the effect of incubation conditions on the standard deviations of assays. A longer incubation time and lower temperature were better for obtaining sensitive and reproducible data (Table I); and $4^{\circ} \mathrm{C}$ for $5 \mathrm{~d}$ for the first incubation, and $4^{\circ} \mathrm{C}$ for $24 \mathrm{~h}$ for the second incubation were adopted in this study.

To assess day-to-day and within day reproducibilities, standard samples in the buffer were prepared and the radioimmunoassay was carried out on three different days. On each day three series of standard samples were assayed and three standard curves were drawn; each curve was derived from assays of triplicate samples. These $\log$ it $\left(B / B_{0}\right)$ versus $\log c$ in the buffer were subjected to a least squares best fit to a straight line using a computer (Fig. 1). These $\operatorname{logit}\left(B / B_{0}\right)$ were reinserted into the equation to calculate the concentration of TRH in the buffer (Table II). The radioimmunoassay appears

TABLE II. Within-Day and Day-to-Day Reproducibilities Using Mean Calculated Levels from the Radioimmunoassay

\begin{tabular}{|c|c|c|c|c|c|c|c|c|c|c|c|}
\hline \multicolumn{12}{|c|}{ Theoretical drug concentration in buffer ( $\mathrm{pg} / \mathrm{sample}$ as TRH) } \\
\hline & 2.5 & 5 & 10 & 20 & 40 & 80 & 160 & 320 & 625 & 1250 & 2500 \\
\hline & \multicolumn{11}{|c|}{ First day } \\
\hline $\begin{array}{l}\text { Mean } \\
(n=3)\end{array}$ & 0 & 4.6 & 9.9 & 16.7 & 42.7 & 91.4 & 177.1 & 315.7 & 547.0 & \multicolumn{2}{|c|}{1183.42063 .7} \\
\hline S.E. & 0 & 1.1 & 0.4 & 2.5 & 9.1 & 9.0 & 9.1 & 11.0 & 13.5 & 86.4 & 64.7 \\
\hline & & \multicolumn{10}{|c|}{ Second day } \\
\hline $\begin{array}{l}\text { Mean } \\
(n=3)\end{array}$ & 1.5 & 10.2 & 21.4 & 23.0 & 47.3 & 67.9 & 162.2 & 342.7 & 527.4 & \multicolumn{2}{|c|}{1164.22072 .5} \\
\hline S.E. & 0.6 & \multirow{2}{*}{\multicolumn{10}{|c|}{ Third day }} \\
\hline & & & & & & & & & & & \\
\hline $\begin{array}{l}\text { Mean } \\
(n=3)\end{array}$ & 1.7 & 9.8 & 14.4 & 29.0 & 63.9 & 101.4 & 165.9 & 363.3 & 589.8 & 1273.0 & 2128.6 \\
\hline S.E. & 0.5 & 1.7 & 4.9 & 2.9 & 8.5 & 12.9 & 3.9 & 62.9 & 60.2 & 113.4 & 184.7 \\
\hline & \multicolumn{11}{|c|}{ Average of the nine standard curves } \\
\hline $\begin{array}{l}\text { Mean } \\
(n=9)\end{array}$ & 1.1 & 8.2 & 15.2 & 22.9 & 51.3 & 86.9 & 168.4 & 340.5 & 554.7 & 1206.9 & 2088.3 \\
\hline $\begin{array}{l}\text { S.E. } \\
\text { Percent }\end{array}$ & 0.6 & 2.7 & 3.3 & 3.6 & 8.0 & 10.7 & 8.8 & 28.9 & 28.6 & 68.5 & 87.7 \\
\hline $\begin{array}{l}\text { Percent } \\
\text { theory } \\
\text { (\%) }\end{array}$ & 44 & 164 & 152 & 114 & 128 & 109 & 105 & 108 & 89 & 97 & 84 \\
\hline
\end{tabular}


TABLE III. Cross Reactivities of TRH Analogs with TRH-Antiserum

\begin{tabular}{lc}
\hline \hline Compound & Cross reactivity \\
& relative to TRH \\
\hline L-Pyroglutamyl-L-histidyl-L-proline (TRH-OH) & $<0.001$ \\
L-Glutamyl-L-histidyl-L-prolineamide & 0.20 \\
L-Glutamyl-L-histidyl-L-proline & $<0.001$ \\
L-Glutamyl-L-histidine & $<0.001$ \\
L-Histidyl-L-proline & $<0.001$ \\
L-Glycyl-L-glycyl-L-glycine & $<0.001$ \\
L-Glycyl-L-glycine & $<0.001$ \\
L-Glycine & $<0.001$ \\
L-Glycyl-L-proline & $<0.001$ \\
L- $\beta$-Alanyl-L-histidine & $<0.001$ \\
\hline
\end{tabular}

TABLE IV. The Effect of BAL on the Sensitivity of TRH Radioimmunoassay in the Buffer and Rat Plasma (Expressed as $B_{c} / T_{c} \%$ )

\begin{tabular}{|c|c|c|c|c|}
\hline \multirow{2}{*}{$\begin{array}{l}\text { BAL } \\
\text { added (mM) }\end{array}$} & \multirow{2}{*}{\multicolumn{2}{|c|}{$\begin{array}{l}\text { In buffer TRH-T } \\
\text { (as TRH) }\end{array}$}} & \multicolumn{2}{|c|}{$\begin{array}{l}\text { In rat plasma }(0.1 \mathrm{ml}) \\
\text { TRH-T (as TRH) }\end{array}$} \\
\hline & & $10.0 \mathrm{ng}$ & $0 \mathrm{pg}$ & $10.0 \mathrm{ng}$ \\
\hline 0 & $76.3 \%$ & $34.3 \%$ & $78.7 \%$ & $58.9 \%$ \\
\hline 0.2 & 76.6 & $33.7^{b)}$ & $77.1^{a)}$ & $51.2^{a)}$ \\
\hline 0.5 & $69.7^{b)}$ & $33.2^{b)}$ & $74.1^{b)}$ & $34.2^{b)}$ \\
\hline 1 & $66.9^{b)}$ & $32.0^{b)}$ & $73.2^{b)}$ & $33.4^{b)}$ \\
\hline 2 & $66.5^{b)}$ & $31.5^{b)}$ & $70.8^{b)}$ & $33.2^{b)}$ \\
\hline
\end{tabular}

a) $p<0.05$, b) $p<0.01$, significantly different from control (BAL $0 \mathrm{mM})$.

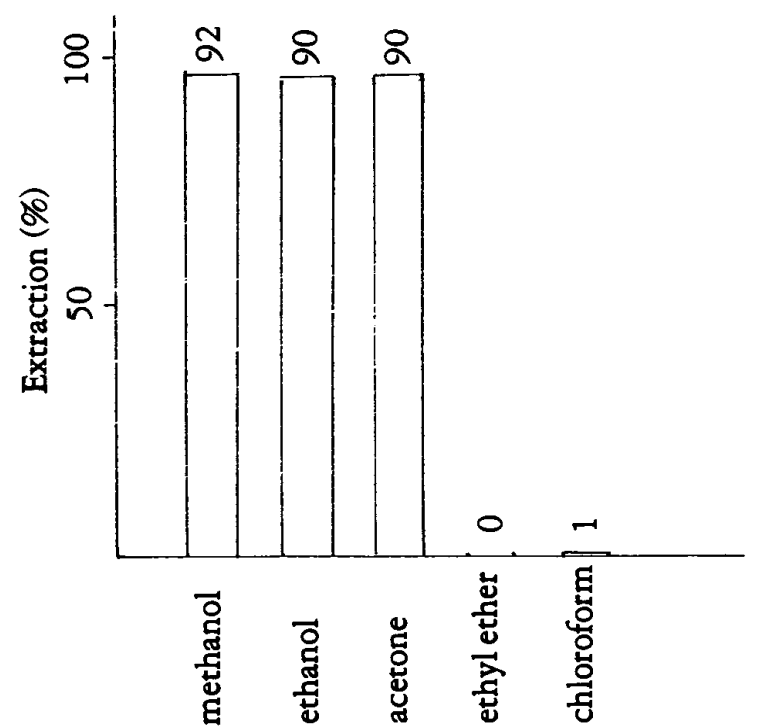

FIG. 2. The Extracting Ability of Organic Solvents

The extraction was carried out with the addition of $2 \mathrm{ml}$ organic solvent to $0.5 \mathrm{ml}$ rat whole blood containing 14.6ng TRH-T (e.q. 10ng of TRH). to be most suitable for determining TRH in the range of more than $20 \mathrm{pg} / \mathrm{sample}$, with relative standard errors $(n=3)$ mostly within $10 \%$. The averages of TRH levels from the nine standard curves were in good agreement with theoretical values. The average (e.q. 5-2 $500 \mathrm{pg}$ of TRH) of the relative standard errors for the means within day was $8.5 \%$ and for day-to-day was 7.9\%; this shows good within day and dayto-day reproducibility.

Specificity of Radioimmunoassay

The relative activity of antiserum to gluhis-proNH $\mathrm{N}_{2}$, the only compound to show significant cross reactivity with $\mathrm{TRH}$, was $20 \%$ ( $\mathrm{TRH}=100 \%$ ) (Table III). This compound, however, is not a main metabolite of TRH in whole blood. ${ }^{20,27,28)}$ Schally suggested that, during incubation with human plasma, TRH un- 
dergoes cleavage of amide group at the propyl end, giving rise to the free acid, (pyro) gluhis-pro (TRH-OH) ${ }^{20)}$ However, (pyro) gluhis-pro had no immunocross reactivity with TRH to the antiserum used.

Thus, it can be concluded that analog compounds did not interfere significantly and the method is very sensitive for the assay of TRH in blood.

Degradation of TRH in Whole Blood and TRH Degrading Enzyme Inhibitors

Several researchers have reported that TRH is quickly degraded in rat and human serum, 14, 20) and 2,3-dimercapto-1-propanol (BAL) has been suggested as a degrading enzyme inhibitor

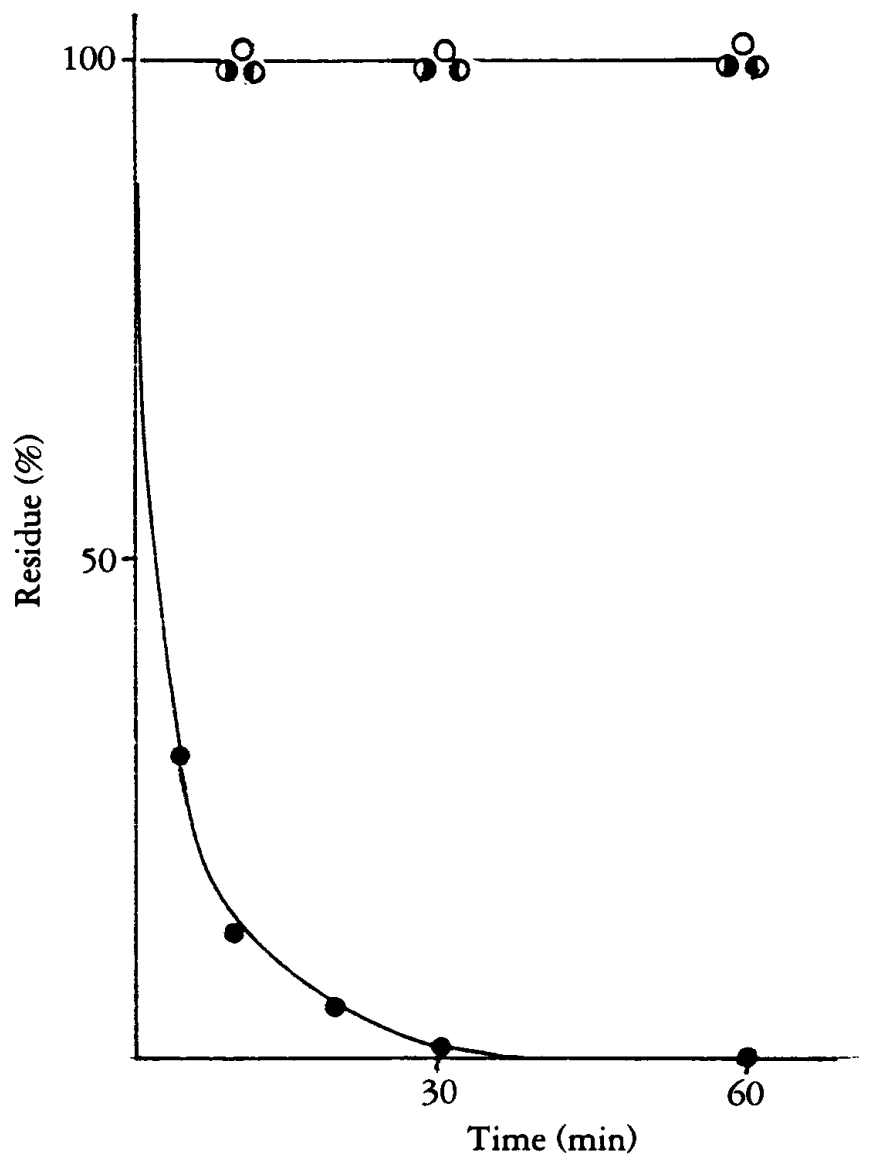

FIG. 3. Stability of TRH-T during Incubation in Rat Whole Blood with or without an Organic Solvent at $37^{\circ} \mathrm{C}$

-, without organic solvents; $\bigcirc$, with $\mathrm{MeOH}$; $\boldsymbol{0}$, with ethanol; $\mathbf{0}$, with acetone. during serum separation and incubation for the radioimmunoassay. ${ }^{21)}$ Several amounts of BAL were added to the buffer or rat plasma with TRH $(0.1 \mathrm{ml})$ and radioimmunoassay was performed about these samples. More than $0.5 \mathrm{mM}$ of BAL decreased the formation of antibodysubstrate complex in the buffer, and less than

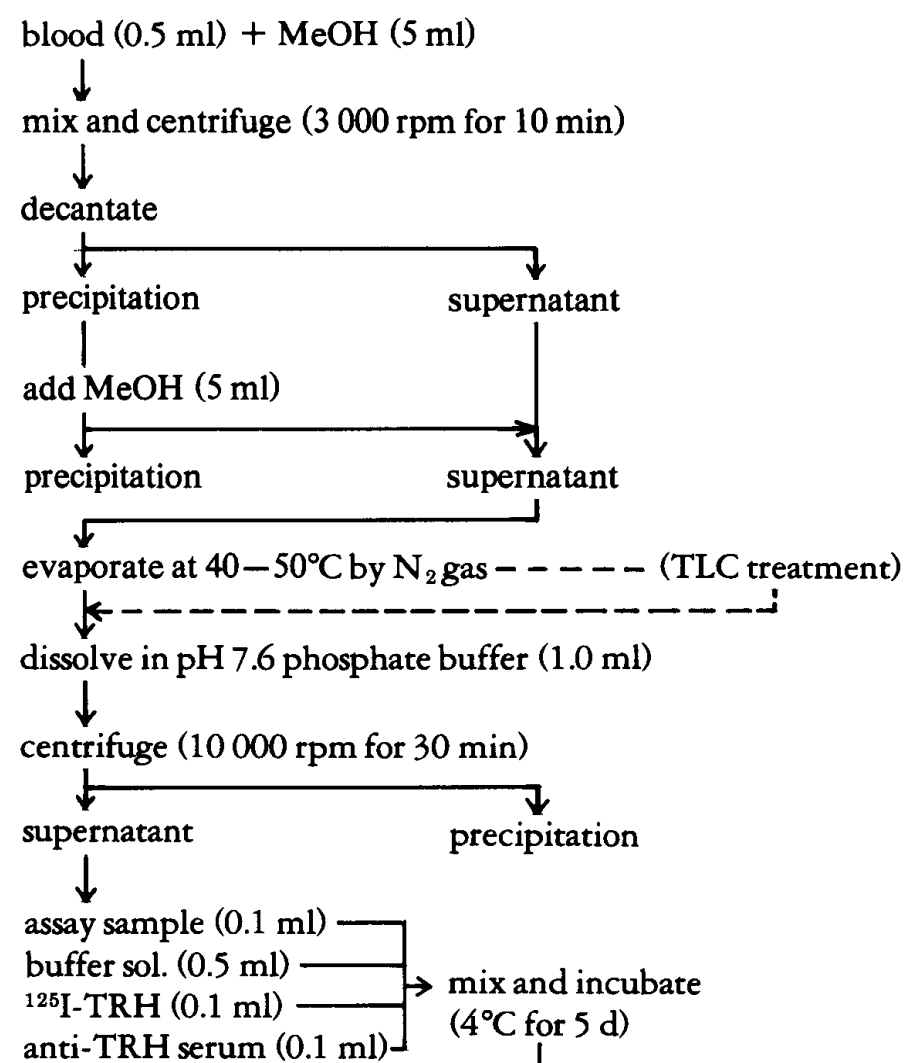

CHART 1. Process of TRH Radioimmunoassay 
could not inhibit degradation of TRH in rat whole blood or plasma (Table IV). Almost the same results were obtained about beagle-dog and human whole blood. Even during the period

TABLE V. The Effect of Quantity of Rat whole Blood or Condition of Food Ingestion on the Sensitivity of TRH Radioimmunoassay

\begin{tabular}{lclll}
\hline \hline Sample No. & $\begin{array}{l}\text { Spiked TRH-T } \\
(\mathrm{pg} \text { as TRH) }\end{array}$ & $\begin{array}{l}\text { Whole blood } \\
\text { amounts }(\mathrm{ml})\end{array}$ & $\begin{array}{l}\text { Food } \\
\text { condition }\end{array}$ & $\begin{array}{l}B_{\mathrm{c}} / T_{\mathrm{c}} \\
(\%)\end{array}$ \\
\hline No.1 & 100 & 0.2 & $24 \mathrm{~h}$ fasting & $45.3 \%$ \\
No.2 & 100 & 0.2 & After meal & $\left.42.9^{a}\right)$ \\
No.3 & 100 & 1.0 & $24 \mathrm{~h}$ fasting & $\left.42.7^{a}\right)$ \\
No.4 & 400 & 0.2 & $24 \mathrm{~h}$ fasting & 38.2 \\
No.5 & 400 & 0.2 & After meal & $36.4 \mathrm{~b})$ \\
No.6 & 400 & 1.0 & $24 \mathrm{~h}$ fasting & $\left.35.7^{b}\right)$ \\
No.7 & 1000 & 0.2 & 24 h fasting & 32.2 \\
No.8 & 1000 & 0.2 & After meal & 32.0 \\
No.9 & 1000 & 1.0 & 24 h fasting & 31.9 \\
\hline
\end{tabular}

a) $p<0.01$ significantly different from No.1 sample.

b) $p<0.01$ significantly different from No.4.sample.

TABLE VI. Recovery from TLC Treatment of TRH in Beagle-Dog Blood

\begin{tabular}{|c|c|c|c|c|}
\hline $\begin{array}{l}\text { Assayed } \\
\text { sample No. }\end{array}$ & Condition & $\begin{array}{l}\text { TRH } \\
\text { added (ng) }\end{array}$ & $\begin{array}{l}\text { Contents calc. } \\
\text { from stn. curve (ng) }\end{array}$ & $\begin{array}{l}\text { Recovery } \\
(\%)\end{array}$ \\
\hline No.1 & TLC developed of stn. soln. & 0.05 & 0.035 & 70 \\
\hline No.2 & TLC developed of stn. soln. & 1.0 & 0.68 & 68 \\
\hline No.3 & TLC developed of stn. soln. & 10.0 & 7.1 & 71 \\
\hline No.4 & TLC developed of stn. soln. & 50.0 & 35.3 & 71 \\
\hline No.5 & $\begin{array}{l}\text { Spiked and extracted from } \\
\text { beagle-dog blood in vitro }\end{array}$ & 0.05 & 0.048 & 96 \\
\hline No.6 & $\begin{array}{l}\text { Spiked and extracted from } \\
\text { beagle-dog blood in vitro }\end{array}$ & 1.0 & 0.95 & 95 \\
\hline No.7 & $\begin{array}{l}\text { Spiked and extracted from } \\
\text { beagle-dog blood in vitro }\end{array}$ & 10.0 & 9.8 & 98 \\
\hline No.8 & $\begin{array}{l}\text { Spiked and extracted from } \\
\text { beagle-dog blood in vitro }\end{array}$ & 50.0 & 48.5 & 97 \\
\hline No.9 & TLC developed of sample No.5 & 0.05 & 0.032 & $67^{a)}$ \\
\hline No.10 & TLC developed of sample No.6 & 1.0 & 0.65 & $68^{b)}$ \\
\hline No.11 & TLC developed of sample No.7 & 10.0 & 7.2 & $73^{c)}$ \\
\hline No.12 & TLC developed of sample No.8 & 50.0 & 35.5 & $73^{d)}$ \\
\hline No.13 & $\begin{array}{l}\text { Beagle-dog blood sample } \\
\text { (TRH-T administered) }\end{array}$ & & 0.58 & 100 \\
\hline No.14 & TLC developed of sample No.13 & & 0.40 & $69^{e)}$ \\
\hline
\end{tabular}

a) compared with sample No.5.

b) compared with sample No.6.

c) compared with sample No.7.

d) compared with sample No.8.

e) compared with sample No.13. 
TABLE VII. Recovery from TLC Treatment of TRH in Human Blood

\begin{tabular}{|c|c|c|c|c|}
\hline $\begin{array}{l}\text { Assayed } \\
\text { sample No. }\end{array}$ & Condition & $\begin{array}{l}\text { TRH } \\
\text { added (ng) }\end{array}$ & $\begin{array}{l}\text { Contents calc. } \\
\text { from stn. curve (ng) }\end{array}$ & $\begin{array}{l}\text { Recovery } \\
(\%)\end{array}$ \\
\hline No.15 & $\begin{array}{l}\text { Spiked and extracted from } \\
\text { human blood in vitro }\end{array}$ & 0.05 & 0.06 & 120 \\
\hline No.16 & $\begin{array}{l}\text { Spiked and extracted from } \\
\text { human blood in vitro }\end{array}$ & 1.0 & 1.02 & 102 \\
\hline No.17 & $\begin{array}{l}\text { Spiked and extracted from } \\
\text { human blood in vitro }\end{array}$ & 10.0 & 9.7 & 97 \\
\hline No.18 & $\begin{array}{l}\text { Spiked and extracted from } \\
\text { human blood in vitro }\end{array}$ & 50.0 & 48.8 & 98 \\
\hline No.19 & TLC developed of sample No.15 & 0.05 & 0.034 & $57^{a)}$ \\
\hline No.20 & TLC developed of sample No.16 & 1.0 & 0.69 & $68^{b)}$ \\
\hline No.21 & TLC developed of sample No.17 & 10.0 & 7.2 & $\left.74^{c}\right)$ \\
\hline No.22 & TLC developed of sample No.18 & 50.0 & 35.0 & $72^{d)}$ \\
\hline
\end{tabular}

a) compared with sample No.15. c) compared with sample No.17.

b) compared with sample No.16.

d) compared with sample No.18.

of separation of plasma from whole blood, large amounts of TRH were degraded. ${ }^{26)}$ Organic solvents, $\mathrm{MeOH}$, ethanol, acetone, chloroform, and ethylether were tested for the direct extraction and for the TRH degrading enzyme inhibitors in whole blood. The results are shown in Fig. 2 . Chloroform and ethylether did not extract sufficient amounts of TRH from the buffer or from rat, beagle-dog and human whole blood. $\mathrm{MeOH}$, ethanol and acetone did stabilize TRH in whole blood at $4^{\circ} \mathrm{C}$ and $37^{\circ} \mathrm{C}$ (Fig. 3). Therefore, in the experiments, $\mathrm{MeOH}$ was used as TRH degrading enzyme inhibitor and for extracting TRH from whole blood. The procedures of the radioimmunoassay are summarized in Chart 1.

Factors Affecting the Sensitivity of Radioimmunoassay of TRH

The interference of serum lipids, triglycerides, triolein, and phosphatidylcholine in radioimmunoassay has been reported. ${ }^{22,}{ }^{23)}$ Food ingestion, for example, would have some effect on the formation of an antibody-substrate complex. Therefore, some factors that would affect the sensitivity of the radioimmunoassay of TRH were examined by TLC experiments. In the case of high concentration of TRH, more than $1 \mathrm{ng}$, neither the quantity of the whole blood nor the condition of food ingestion, i.e., $24 \mathrm{~h}$ fasting or just after meal, affected the sensitivity of the radioimmunoassay of $T R H$. But when rather low concentration of TRH, i.e., less than $1 \mathrm{ng}$, were assayed, the quantity of whole blood and food ingestion decreased the sensitivity of the radioimmunoassay (Table $\mathrm{V}$ ). Therefore, the same quantity of whole blood (in the same condition of food ingestion) was needed for preparing the standard curve. In Table VI and VII, TLC recoveries were $70 \%$ in the range of 0.05-50 ng and were not decreased by the addition of animal whole blood (either $24 \mathrm{~h}$ fasting or after meal) or human whole blood (either 12 $h$ fasting or after meal) in the range of $0.05-1$ ng. Thus, TLC treatment improved the sensitivity of the radioimmunoassay of TRH in the whole blood when assay was made after meal or when large amounts of whole blood were required because low concentrations of TRH were assayed.

By this method, TRH in the whole blood of rats, beagle-dogs, and humans can be measured and the evaluation of the bioavailability of TRH-T and the investigation of its absorption mechanism from gastrointestine would be able 
to be carried out.

Acknowledgement The authors would like to acknowledge the valuable suggestion about the methods of radioimmunoassay of Dr. N. Nihei, Hamamatsu University School of Medicine, and the continuing guidance of Drs. Y. Nagawa and T. Shimamoto, Takeda Chemical Industries, Ltd.

\section{REFERENCES}

1) R.M.Bassiri and R.D.Utiger: Thyrotropin-releasing hormone in the hypothalamus of the rat, Endocrinology, 94, 188-197 (1974).

2) G.Grant, W.Vale and R.Guillemin: Interaction of thyrotropin releasing factor with membrane receptors of pituitary cells, Biochem. Biophys. Res. Commun., 46, 28-34 (1972).

3) G.Grant, W.Vale and R.Guillemin: Characteristics of the pituitary binding sites for thyrotropin-releasing factor, Endocrinology, 92, 1629-1633 (1973).

4) C.Oliver, J.P.Chavet, J-L.Codaccioni and J.Vague: Radioimmunoassay of thyrotropin-releasing hormone (TRH) in human plasma and urine, J.Clin. Endocrinol. Metab., 39, 406-409 (1974).

5) C.Oliver, R.L.Eskay, N.Ben-Jonathan and J.C.Porter: Distribution and concentration of $\mathrm{TRH}$ in the rat brain, Endocrinology, 95, 540 - 546 (1974).

6) I.M.D.Jackson and S.Reichlin: Thyrotropin-releasing hormone (TRH): Disribution in hypothalamic and extrahypothalamic brain tissues of mammalian and submammalian chordates, Endocrinology, 95, 854-862 (1974).

7) J.Boler, F.Enzmamm, K.Folkers, C.Y.Bowers and A.V.Schally: The identity of chemical and hormonal properties of the thyrotropin releasing hormone and pyroglutamyl-histidyl-proline amide, Biochem. Biohys. Res. Commun., 37, 705-710 (1969).

8) N.Fleischer, R.Burgus, W.Vale, T.Dunn and R.Guillemin: Preliminary observations on the effects of synthetic thyrotropin releasing factors on plasma thyrotropin levels in man, J.Clin. ENdocrinol. Metab., 31, 109-112 (1970).

9) A.J.Kastin, R.H.Ehrensing, D.S.Schalch and M.S.Anderson: Improvement in mental depression with decreased thyrotropin response after administration of thyrotropin-releasing hormone, Lancet, 2, 740-742 (1972).

10) A.J.Prange Jr., I.C.W ilson, P.P.Lara, L.B.Alltop and G.R.Breese: Effect of thyrotropin-releasing hormone in depression, Lancet, 2, 999-1002 (1972).

11) T.M.Itil, C.D.Patterson, N.Polvan, A.Bibelow and B.Bergey: Clinical and CNS effects of oral and $i$. v. thy- rotropin releasing hormone in depressed patients, Dis. Nerv. Syst., 36, 529-536 (1975).

12) C.Hatanaka, M.Obayashi, O.Nishimura, N.Toukai and M.fujino: An improved synthesis of thyrotropin releasing hormone (TRH) and crystallization of the tartrate, Biochem. Biophs. Res. Commun., 60, $1345-1350$ (1974).

13) C.Hatanaka, H.Nakamachi, M.Kaneko, H.Yonezawa, N.Toukai and M.Fujino: Synthesis and polymorphs of TRH L-tartrate (TRH-T), J.Takeda Res. Lab., 35, 16-22 (1976).

14) N.White, S.L. Jeffcoate, E.C.Griffiths and K.C.Hooper: Effect of thyroid status on the thyrotropin-releasing hormone-degrading activity of rat serum, J. Endocrinol., 71, 13-19 (1976).

15) S.L.Jeffcoate and N.White: Use of benzamidine to prevent the destruction of thyrotropin-releasing hormone (TRH) by blood, J. Clin. Endocrinol. Metab., 38, 155-157 (1974).

16) T.Mitsuma, Y.Hirooka and N.Hihei: Radioimmunoassay of thyrotropin releasing hormone in human serum and its clinical application, Acta endocr., 83, 225-235 (1976).

17) R.M.Bassiri and R.D.Utiger: The preparation and specificity of antibody to thyrotropin releasing hormone, Endocrinology, 90, $722-727$ (1972).

18) N.Nakajima, K.Yoshida and Y.Asahi: Physicochemical properties, stabilities and analysis of TRH Ltartrate (TRH-T), J. Takeda Res. Lab., 35, 23-33 (1976).

19) F.C.Greenwood, W.H.Hunter and J.S.Glover: The preparation of ${ }^{131} \mathrm{I}$-labelled human growth hormone of high specific radioimmunoassay, Biochem. J., 89, 114-123 (1963).

20) A.Dupont, F.Labrie, L.Levasseur, J.H.Dussault and A.V.Schally: Effect of thyroxine on the inactivation of thyrotropin-releasing hormone by rat and human plasma, Clin. Endocrinol., 5, 323-330 (1976).

21) R.D.Utiger and B.M.Bassiri, "Hypothalamic hypophysiotropic hormone," ed. by C.Gual and E.Rosemberg, Excerpta Medica, Amsterdam, 1973, p. 146.

22) J.M.Rash, I.Jerkunica and D.S.Sgoutas: Lipid interference in steroid radioimmunoassay, Clin. Chem., 26, 84-88 (1980).

23) M.J.Jawad, E.A.Wilson and W.F.Rayburn: Effect of serum lipids on radioimmunoassays of unconjugated estriol in serum, Clin. Chem., 27, 280-285 (1981).

24) N.Nihei, S.Watabe, K.Yamauchi, Y.Imai, K.Kataoka, I.Ishihara: Study on the inactivation of TRH by human plasma, Ann. Rep Environ. Med. Nagoya Univ., XXVIII, 1977, pp. $121-123$

25) M.Utsumi, M.Tatsuiwa, T.Kusaka, H.Makimura and M.Sakoda: The measurement of TRH by radioimmunoassay, Igakunoayumi, 93, 101 -103 (1975).

26) T.W.Redding and A.V. Schally: Studies on the inacti- 
vation of thyrotropin-releasing hormone (TRH), Proc. Soc. Exp. Biol. Med., 131, 415-420 (1969).

27) R.M.G.Nair, T.W.Redding and A.V.Schally: Site of inactivation of thyrotropin-releasing hormone by human plasma, Biochemistry, 10,3621 -3624 (1971).

28) T.W.Redding and A.V.Schally: On the half life of thyrotropin-releasing hormone in rats, Neuroendocrinology, 9, 250-256 (1972). 